Yeast

Yeast 2007; 24: 000-000.

Published online in Wiley InterScience

(www.interscience.wiley.com) DOI: 10.1002/yea.I548

\title{
The transcriptional inhibitor thiolutin blocks mRNA degradation in yeast
}

\author{
Vicent Pelechano and José E. Pérez-Ortín* \\ Departamento de Bioquímica y Biología Molecular, Universitat de València, CIDr. Moliner 50, E46I 00 Burjassot, Spain
}

*Correspondence to: José E. Pérez-Ortín,

Departamento de Bioquímica y Biología Molecular, C/Dr. Moliner 50, 46100 Burjassot, València, Spain.

E-mail: jose.e.perez@uv.es

Received: I 4 March 2007

Accepted: 31 July 2007

\begin{abstract}
Thiolutin is commonly used as a general inhibitor of transcription in yeast. It has been used to calculate mRNA decay rates by stopping the transcription and then determining the relative abundance of individual mRNAs at different times after inhibition. We report here that thiolutin is also an inhibitor of mRNA degradation, and thus its use can lead to miscalculations of mRNA half-lives. The inhibition of mRNA decay seems to affect the mRNA degradation pathway without impeding poly(A) shortening, given that the decay rate of total poly(A) amount is not reduced by thiolutin. Moreover, the thiolutin-dependent inhibition of mRNA degradation has variable effects on different functional groups of genes, suggesting that they use various degradation pathways for their mRNAs. Copyright (c) 2007 John Wiley \& Sons, Ltd.
\end{abstract}

Keywords:

\section{Introduction}

The process of eukaryotic gene expression involves several regulated steps at the mRNA level. mRNA is transcribed by RNA polymerase II and exported to the cytoplasm. There, the turnover rate of mRNA is regulated by different pathways. In yeast, two main routes for mRNA degradation exist. In both decay pathways, the degradation of mRNA is initiated by the shortening of the poly(A) tail at the $3^{\prime}$ end (reviewed in Parker and Song, 2004). Then, either the cap structure of the $5^{\prime}$ end is removed and the transcript degraded by a $5^{\prime} \rightarrow 3^{\prime}$ exonuclease or, alternatively, the mRNA is degraded by a series of $3^{\prime} \rightarrow 5^{\prime}$ exonucleolytic steps.

The study of mRNA stability in eukaryotic systems is receiving increasing attention because it is becoming evident that it is an important regulatory mechanism for gene expression (Cheadle et al., 2005; Mata et al., 2005; Pérez-Ortín et al., 2007; Sunnerhagen, 2007). There are several different methods of studying mRNA stability in yeast and other eukaryotes (Parker et al., 1991; Mata et al., 2005). All of them have some drawback (dis- 25 cussed in Parker et al., 1991; Sunnerhagen, 2007). 26 The use of antibiotic drugs that inhibit RNA poly- 27 merase II is one of the preferred methods because 28 of its simplicity and its application to all kinds 29 of yeast strains. The most commonly used antibi- 30 otic is thiolutin (Jiménez et al.,1973), a metabo- 31 lite produced by Streptomyces luteoreticuli (Celmer 32 and Solomon, 1955) that inhibits all yeast RNA 33 polymerases, mainly at the level of initiation (Tip- 34 per, 1973). However, it has also been reported to 35 inhibit elongation in E. coli (Khachatourians and 36 Tipper, 1974). It is commonly used at concentra- 37 tions around $3 \mu \mathrm{g} / \mathrm{ml}$ but in some cases use of 38 higher concentrations has been reported (Michan et al., 2005; Guan et al., 2006). The appearance of genomic techniques for the measurement of mRNA stabilities (Wang et al., 2002; Grigull et al., 2004) has incorporated the use of thiolutin at the genomic level. Despite its known effects as an inhibitor of translation (Jiménez et al., 1973; Tipper, 1973) and as an elicitor of stress responses (Adams and Gross, 1991; Grigull et al., 2004), the use of this antibiotic 
1 is becoming more important in gene expression 2 studies in yeast.

Here, we report that thiolutin has an inhibitory effect on mRNA degradation that becomes apparent at concentrations higher than $3 \mu \mathrm{g} / \mathrm{ml}$. Because this effect involves the same process, mRNA stability, which is the goal of the studies that use thiolutin, its importance cannot be neglected. We have found that the apparent half-lives measured in individual or global mRNA stability studies are probably longer than the real ones, especially when using higher concentrations of thiolutin.

\section{Materials and methods}

Yeast strains, growth conditions, and sampling procedure for half-lives determination

The yeast strains BQS252 (MAT a, ura3-52, derived from FY1679) and Z676 [MATa, his3, leu2-3, ura3-52, rpb1::HIS3 transformed with plasmid RY2522 (rpb1-1, URA3, CEN, AMP)] were used. Cells were grown in YPD (yeast extract $1 \%$, peptone $2 \%$, glucose $2 \%$ ) with agitation at $28^{\circ} \mathrm{C}$ and recovered by centrifugation at $\mathrm{OD}_{600}=0.5$. Cell samples were taken at different times after thiolutin addition and were frozen in liquid $\mathrm{N}_{2}$. RNA samples were purified by phenol extraction as described (García-Martínez et al., 2004). For heatshock experiments, pre-warmed $\left(65^{\circ} \mathrm{C}\right)$ YPD was added to the culture at $25^{\circ} \mathrm{C}$ in order to quickly increase the temperature to $37^{\circ} \mathrm{C}$. Then samples were taken as previously described. Thiolutin was a gift from Pfizer. Several different batches were used.

\section{Northern blot analysis}

Electrophoresis was done in $1 \%$ agarose in $1 \times$ MOPS and $6.4 \%$ formaldehyde. The samples were transferred to a nylon membrane (Hybond $\mathrm{N}^{+}$, Amersham) by capillarity with $6 \times$ SSC overnight and UV crosslinked. Then the filter was hybridized for $16 \mathrm{~h}$ at $42^{\circ} \mathrm{C}$ in $50 \%$ formamide, $5 \times$ SSPE, $5 \%$ dextran sulphate, $0.5 \%$ SDS, $5 \times$ Denhardt's solution and salmon sperm DNA $200 \mu \mathrm{g} / \mathrm{ml}$. DNA probes for ACT1 and RPL24 were obtained by PCR. The probes cover the entire ORF and were labelled by random primer using ${ }^{33} \mathrm{P}$-dCTP and Ready-to-Go kit (Amersham). The filters were washed twice during $10 \mathrm{~min}$ at $42^{\circ} \mathrm{C}(2 \times \mathrm{SSPE}$ and $0.1 \%$ SDS) and once during $15 \mathrm{~min}$ at $65^{\circ} \mathrm{C} 52$ (1× SSPE and $0.1 \%$ SDS) and exposed to an 53 imaging plate (BAS-MP, Fujifilm). 54

55

Poly(A) RNA measurement $\quad 56$

A dot-blot procedure to estimate the proportion 57 of poly(A) mRNA in the total RNA was used. 59 Three different dilutions of total RNA extracted 60 from each time point were spotted, using a BioGrid 61 robot (BioRobotics) on a nylon filter. The fil- 62 ter was hybridized with ${ }^{32} \mathrm{P}-5^{\prime}$-labelled poly(dT) 63 as described previously (García-Martínez et al., 64 2004.) These data were used to calculate the pro- 65 portion of poly(A) mRNA in each sample. $\quad 66$

\section{Macroarray hybridization $\quad 68$}

cDNA labelling with a $(\mathrm{dT})_{15} \mathrm{VN}$ primer, and 69 hybridization on in-house prepared nylon mem- 70 brane macroarrays were performed as described 71 previously (Alberola et al., 2004). In order to mea- 73 sure the half-life, the intensities were normal- 74 ized to the sum of all spot intensities and re- 75 weighted using the poly(A) dot-blot data. Half- 76 life data for yeast genes obtained in this work are 77 available at: http://scsie.uv.es/chipsdna/chipsdna- 78 e.html\#datos. Original macroarray data were sub- 79 mitted to the GEO database, where they have been 80 assigned Accession Nos GSE7261 and GSE8629. 81

\section{Results $\quad 83$}

Apparent mRNA decay rates depend on the $\quad 85$ thiolutin concentration used $\quad 86$ thiolutin concentration used 87

Thiolutin is commonly used as a transcriptional 88 inhibitor for mRNA half-life determinations in 89 yeast (Parker et al., 1991). Many researchers use 90 $3 \mu \mathrm{g} / \mathrm{ml}$ as the working concentration (Herrick 91 et al., 1990; Grigull et al., 2004) but the use 92 of higher concentrations has also been reported 93 (Michan et al., 2005; Guan et al., 2006). In order 94 to test the working concentration for our experi- 95 ments we tried several different ones in the range 96 $1-30 \mu \mathrm{g} / \mathrm{ml}$. We observed that addition of thio- 97 lutin at concentrations $3 \mu \mathrm{g} / \mathrm{ml}$ or higher stopped 98 growth for several hours in an S288c back- 99 ground strain (not shown). Next, we used 3, 6, 100 10 and $18 \mu \mathrm{g} / \mathrm{ml}$ thiolutin for decay rate calcu- 101 lation (Figure 1). As shown in Figure 1, $3 \mu \mathrm{g} / \mathrm{ml} 102$ 
(A)

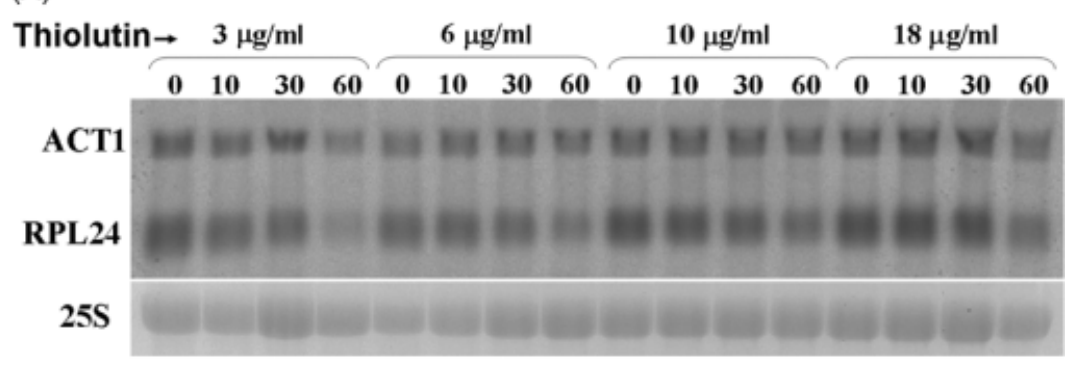

(B)

RPL24

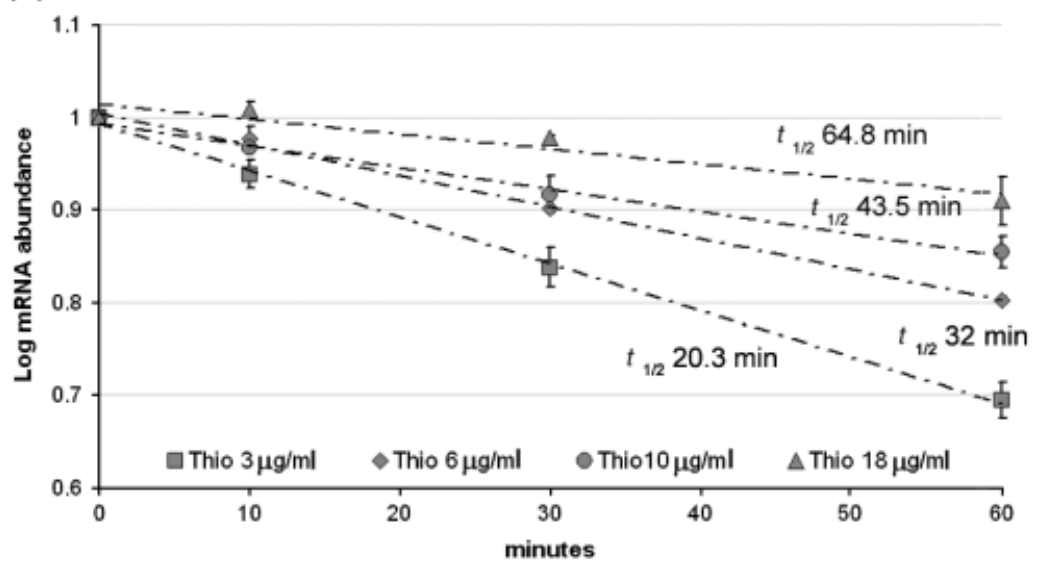

(C) ACT1

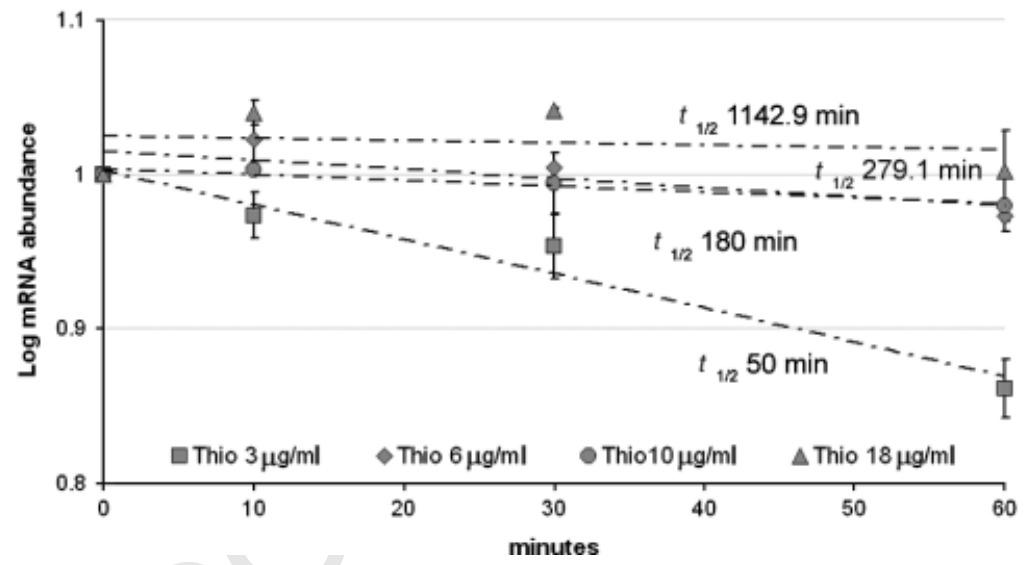

Figure I. Effect of different thiolutin concentrations in the estimation of apparent mRNA half-lives. (A) Northern blot hybridized with probes for ACTI and RPL24 genes of samples taken at different times after the addition of increasing amounts of thiolutin. (B) Calculation of the half-life of RPL24 mRNA for the different thiolutin concentrations shown in (A). (C) Calculation of the half-life of ACTI mRNA for the different thiolutin concentrations shown in (A). The experiments were done in duplicate and the error bars represent the standard deviation between replicates. All samples were normalized using ethidium bromide staining of the 25S rRNA

1 of thiolutin generates estimations of mRNA half-

2 lives that are in agreement with those previously

3 known (31-77 min for ACT1 and 11-24 min

4 for RPL24; Santiago et al., 1986; Herrick et al.,
1990; Wang et al., 2002). However, the addition of higher concentrations of thiolutin leads to the estimation of apparently longer mRNA half-lives in a concentration-dependent manner. This effect
5 6 7

8 
1 depends on the strain used. For instance, W303

2 strain requires $8 \mu \mathrm{g} / \mathrm{ml}$ to obtain results equivalent

3 to those observed using $3 \mu \mathrm{g} / \mathrm{ml}$ in the S288c back-

4 ground (L. Romero-Santacreu and P.M. Alepuz,

5 personal communication). Because it seems unrea-

6 sonable that transcription inhibition decreases with

7 the increase in thiolutin concentration, we conjec-

8 tured that another cellular process was affected.

9 The simplest explanation would be that mRNA

10 degradation was also inhibited by thiolutin.

\section{Thiolutin inhibits mRNA degradation without affecting global poly $(A)$ decay}

To test the hypothesis that thiolutin inhibits mRNA degradation, we used the thermo-sensitive mutant of the large RNA pol II subunit rpbl-1, which is also commonly used for mRNA decay determinations (Parker et al., 1991; Wang et al., 2002; Grigull et al., 2004). As shown in Figure 2, the transcription stop due to a heat shock provokes a continuous decrease in the mRNA amount for ACT1 and RPL24 mRNAs that allows for the measurement of their half-lives. RPL24 and ACT1 apparent half-lives calculated from this experiment were 14 and $34 \mathrm{~min}$ in the absence of thiolutin. However, if thiolutin was added to $20 \mu \mathrm{g} / \mathrm{ml}$ at the same time as the heat-shock, the mRNA amounts remained stable, indicating that, although RNA pol II transcription was stopped by the RNA polymerase inactivation, the mRNA degradation pathways were affected by thiolutin.

In yeast, mRNA degradation pathways begin with the shortening of the $3^{\prime}$ poly(A) tail (Parker and Song, 2004). We wanted to determine whether the total amount of poly(A) tail was affected during the treatment. To address this point, we made a dot-blot analysis of the amount of total poly(A) in the different samples taken after thiolutin addition
(Figure 3). We observed that the poly(A) amount 40 decayed at all thiolutin concentrations used. In fact, 41 the decay was somewhat faster for higher thio- 42 lutin concentrations. Therefore, we concluded that 43 thiolutin-dependent block of mRNA degradation 44 was not due to an overall inhibition of poly(A) 45 shortening.

Thiolutin affects mRNA decay for all genes, but 48 it differentiates between genes according to 49 their function $\quad 50$

51 all yeast genes, we used a similar method to 53 that described by Wang et al. (2002) and Grigull 54 et al. (2004). Samples from cells were taken at 55 $0,10,20,30$ and $45 \mathrm{~min}$ after the addition of 56 $3 \mu \mathrm{g} / \mathrm{ml}$ thiolutin. cDNA was labelled with ${ }^{33} \mathrm{P}-57$ dCTP by oligo- $(\mathrm{dT})_{15} \mathrm{VN}$ priming and hybridized 58

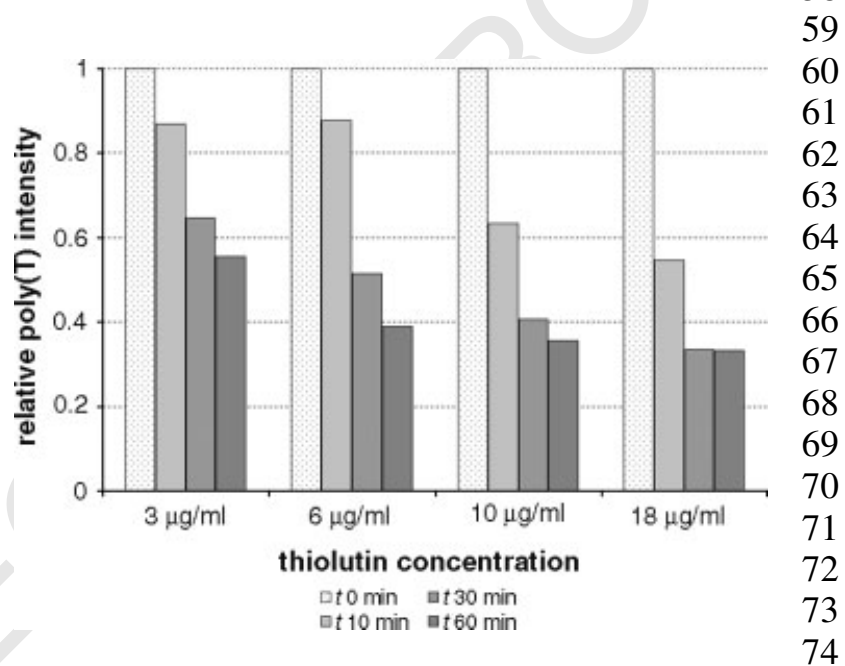

Figure 3. Total poly(A) quantisation after thiolutin 75 treatments. Quantization of the spot intensities from a 76 dot-blot made with total RNA from the samples used in Figure I hybridized with ${ }^{32} \mathrm{P}$-labelled-poly $(\mathrm{T})$. Intensity at time zero (before thiolutin addition) is arbitrarily taken as I

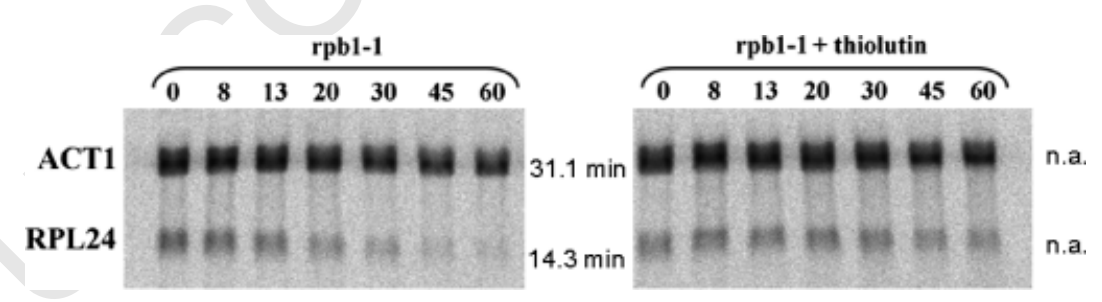

Figure 2. Inhibition of mRNA degradation by thiolutin. Northern blot of samples taken at different times after heat-shock at $37^{\circ} \mathrm{C}$ of the $\mathrm{rpb} / \mathrm{-l}$ strain with or without addition of thiolutin to $20 \mu \mathrm{g} / \mathrm{ml}$. The calculated half-lives are shown on the right of each series. n.a. indicates that the amount of mRNA increases during the experiment and, therefore, half-life calculation is not applicable. All samples were normalized using ethidium bromide staining of the 25S rRNA 
1 to nylon macroarrays as described (Alberola et al.,

2 2004). The use of such an oligonucleotide, which

3 only primes at the beginning of the $\operatorname{poly}(\mathrm{A})$ tail,

4 guarantees that the labelling is only dependent

5 on the number of poly(A) molecules and not on

6 their length. Normalization of the array signals

7 was done using global poly(A) decay. The decay

8 rates data obtained were reasonably similar to those

9 obtained by Grigull et al. (2004) using thiolutin.

10 The correlation coefficient between the degradation

11 constants $(k)$ is 0.40 , which is similar to the

12 correlation observed between the rpbl-1 data of

13 Grigull et al. (2004) and Wang et al. (2002), viz. 140.42.

In order to ensure that increases in thiolutin concentration affected the apparent half-life of all genes, we treated another yeast culture with $10 \mu \mathrm{g} / \mathrm{ml}$ thiolutin and calculated the apparent half-lives. A comparison of the results obtained using the two thiolutin concentrations is shown in Figure 4. The general trend of yeast mRNAs is to increase their apparent half-life, which demonstrates that the thiolutin-dependent effect of mRNA degradation pathways is general. We used the northern blot data from ACT1 (which remains in the same relative position in the two distributions) in order to normalize the two sets of data. However, when analysing the bias of functionallyrelated groups of genes, it was evident that some groups were more affected (apparent half-lives more increased) that the average, e.g. ribosomal proteins and $\mathrm{RiBi}$ regulon (Jorgensen et al., 2004). On the other hand, some groups were less affected than the average, e.g. sulphur amino acid transport, siderophore transport, sulphate assimilation and iron transport. The functional categories present in the second class suggested that the transcription of those genes may be induced in response to the weak stress induced by low concentrations of thiolutin (see Grigull et al., 2004), but that at higher drug concentrations the transcriptional block was too fast to allow gene induction.

\section{Discussion}

The determination of mRNA stability is of increasing relevance because mRNA turnover is emerging as an important factor in the regulation of gene expression in eukaryotic cells (Mata et al., 2005; Pérez-Ortín et al., 2007). In yeast, the use

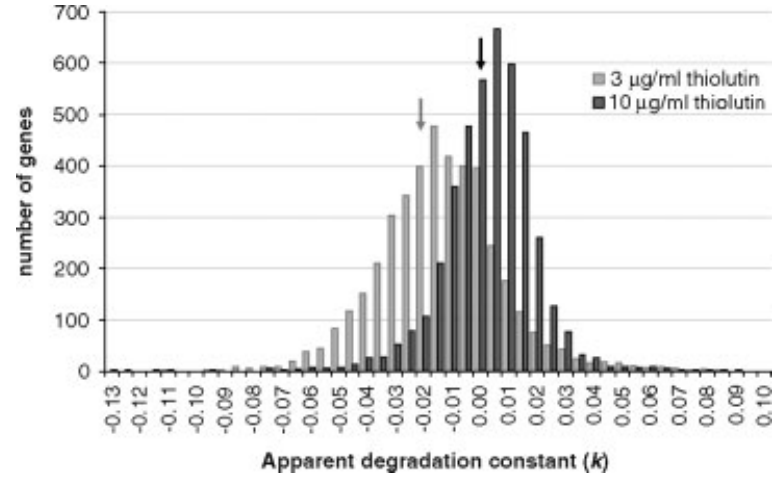

Figure 4. Genomic analysis of thiolutin effect on mRNA decay. Histogram of the apparent degradation constants $\left[k=\left(-I / t_{1 / 2}\right)\right]$ using different thiolutin concentrations. ACTI half-life calculated from Northern blot data (Figure I) was used to normalize the results. This gene remained in the same relative position (marked with an arrow) to the distribution in both cases. The experiments were done in duplicate being the Pearson correlation coefficients between replicates of 0.9 or greater

of antibiotics to inhibit RNA polymerase II tran- 52 scription followed by determination of the rela- 53 tive abundance of the mRNAs is a useful method 54 to evaluate half-lives because it is applicable to 55 any strain. The antifungal thiolutin (Jiménez et al., 56 1973 ) is the most common drug used for this pur- 57 pose. It is thought that thiolutin inhibits all nuclear 58 RNA polymerases by directly interacting with the 59 enzymes and does not inhibit elongating RNA 60 polymerases (Tipper, 1973).

The thiolutin concentration used for mRNA sta- 62 bility experiments in yeast varies in the range 63 3-25 $\mu \mathrm{g} / \mathrm{ml}$ (Adams and Gross, 1991; Grigull 64 et al., 2004; Guan et al., 2006; Minvielle-Sebastia 65 et al., 1991; Herrick et al., 1990; Parker et al., 66 1991; Michan et al., 2005). In general, it is 67 assumed that any concentration above $3 \mu \mathrm{g} / \mathrm{ml} 68$ has, essentially, the same effect (Herrick et al., 69 1991). However, in the course of our work we 70 have noted that the apparent half-lives of several 71 mRNAs vary depending the particular concentra- 72 tion used (Figure 1). Concentrations below (not 73 shown) and above $3 \mu \mathrm{g} / \mathrm{ml}$ lead to mRNA half-life 74 estimates that are longer than expected. Problems 75 with mRNA half-life determination have been pre- 76 viously noted by others (Brendolise et al., 2002). 77 Whereas for lower concentrations this result can 78 be easily explained because of incomplete inhi- 79 bition of the transcriptional activity, the explana- 80 tion for the effect of higher concentrations is not 81 
1 straightforward. We hypothesized that this effect 2 could be the consequence of an additional inhibi3 tion of mRNA degradation at higher concentrations 4 (Figure 5). In fact, thiolutin is known to inhibit 5 other biological processes, such as translation and 6 rRNA processing, when used at $20 \mu \mathrm{g} / \mathrm{ml}$ (Jiménez 7 et al., 1971). The overlapping effect of increas8 ing transcriptional inhibition from low thiolutin 9 concentrations and the increasing mRNA degrada10 tion from higher concentrations would produce a 11 curve with a minimum for half-life determination 12 (Figure 5). According to our data and those from 13 other groups (Guan et al., 2006), the result depends 14 on the particular strain background used.

We have provided experimental evidence for our hypothesis by using a conditional RNA polymerase II mutant strain (Figure 2). As transcription is blocked by temperature inactivation of Rpb1p in this strain, the addition of thiolutin cannot have

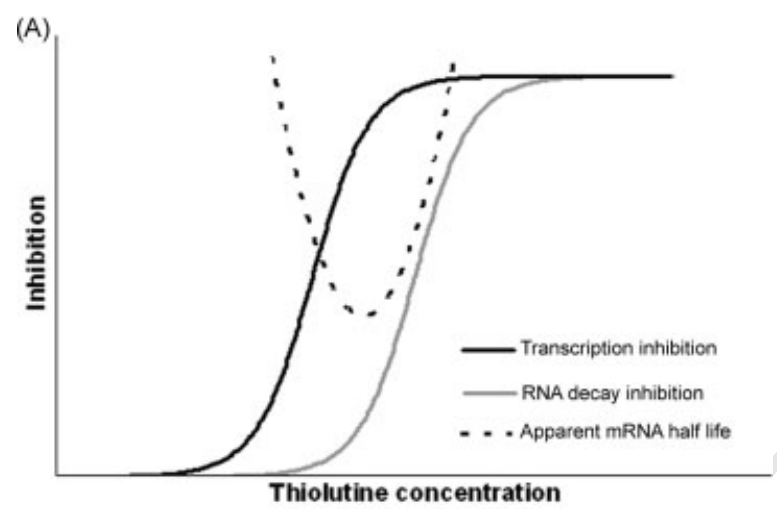

(B)

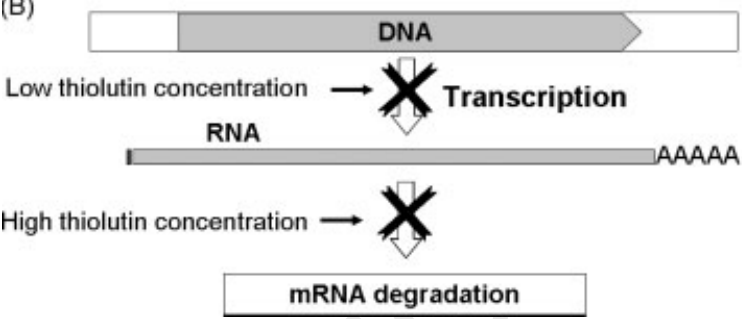

Figure 5. A model for thiolutin actions in yeast cells. (A) Thiolutin inhibition of transcription (black) and of mRNA degradation (grey) provokes a complex response for the measured mRNA half-life. The solid curve represents the approximate effect of transcription and mRNA degradation and the dotted line represents for the predicted sum of effects on apparent half-life. (B) Blocking of transcription occurs at the level of initiation (Tipper, 1973) at any concentration whereas blocking of mRNA degradation occurs only at high concentration (this work) additional effects on transcriptional shut-off if the 52 inactivation is complete. Alternatively, if Rpb1p 53 inactivation were not complete, the shut-off caused 54 by thiolutin would reduce the apparent half-life. 55 Because the relatively high concentration of thio- 56 lutin used $(20 \mu \mathrm{g} / \mathrm{ml})$ produces an increase of the 57 mRNA half-lives, the simpler explanation is that 58 concentration affects the mRNA degradation path- 59 ways. It is interesting to mention that a similar 60 experiment was done by Guan et al. (2006) but 61 using $10 \mu \mathrm{g} / \mathrm{ml}$ of thiolutin. They found, however, 62 that thiolutin did not change the apparent half- 63 life measured. Because the addition of $10 \mu \mathrm{g} / \mathrm{ml} 64$ had an effect on the mRNA half-life determina- 65 tion (Figure 1) in our hands, we think that the 66 discrepancy could be due to variations in the activ- 67 ity of different thiolutin batches. In fact, Guan 68 et al. (2006) found that the W303 background 69 requires 2.5 times $(25 \mu \mathrm{g} / \mathrm{ml})$ higher concentration 70 of thiolutin than for S288c $(10 \mu \mathrm{g} / \mathrm{ml})$ to com- 71 pletely inhibit transcription. This result is in accor- 72 dance with our observation that the W303 strain 73 required 8 instead of $3 \mu \mathrm{g} / \mathrm{ml}$ (2.67 times higher) 74 to obtain the minimum apparent half-life. We also 75 have observed that different thiolutin batches have 76 varying biological activities. These differences are 77 likely due to the fact that thiolutin preparations con- 78 tain important amounts of contaminants - up to 79 $20 \%$ in some batches, as determined by mass spec- 80 trometry (not shown). This would explain the use 81 of higher thiolutin concentrations by other authors 82 (Guan et al., 2006; Michan et al., 2005). 83

In yeast, mRNA degradation is usually started by 84 poly(A) tail shortening (Parker and Song, 2004). 85 We have found that, whereas northern analy- 86 sis shows that individual mRNAs are stabilized 87 by high thiolutin concentrations (Figures 1,2 ) the 88 global poly(A) amount for yeast mRNAs decays 89 at those concentrations (Figure 3). Our results are 90 in agreement with the previous results reported by 91 Minvielle-Sebastia et al. (1991) and Herrich et al. 92 (1990), who showed that blocking transcription 93 either by temperature shift of an rpbl-1 mutant or 94 by addition of thiolutin in a wt strain did not block 95 poly(A) shortening. Northern blots and macroar- 96 ray experiments detect a slower mRNA degrada- 97 tion in the presence of high thiolutin concentration; 98 hence, they are not sensitive to the change in pro- 99 portion between polyadenylated and deadenylated 100 pools of the mRNAs. Although we cannot discard 101 the suggestion that individual mRNA species can 102 
1 have different behaviours, we suggest that inhibi-

2 tion of mRNA degradation occurs after deadeny-

3 lation. It has been shown that thiolutin induces

4 some stress in yeast cells (Grigull et al., 2004) and

5 that stress induces mRNA stabilization (reviewed

6 in Bond, 2006). However, the stress stabilization

7 of mRNA occurs by inhibition of deadenylation

8 (Hilgers et al., 2006), hence the effect of thiolutin

9 cannot be an indirect consequence of the stress.

10 Thiolutin also has an inhibitory effect on transla-

11 tion at high concentrations (Jiménez et al., 1973)

12 and it is known that inhibition of translation blocks

13 mRNA degradation at the level of decapping, with-

14 out inhibiting deadenlylation (Beelman and Parker,

15 1994). Thus, it is possible that the inhibition of

16 mRNA degradation observed by addition of high

17 thiolutin concentrations is due to its effect on trans-

18 lation.

19 Our study shows that the effect of thiolutin

20 on mRNA degradation is at the genomic level.

21 We found that 3533 genes of the 4222 analysed

22 had an increase in their apparent mRNA half-life

23 (Figure 4). This effect was, however, not identical

24 for all of them. For some groups related to sulphur,

25 sulphate and iron metabolism, the deviation from

26 the average behaviour came, probably, from the

27 physiological stress caused by this drug (Grigull

28 et al., 2004). The apparent half-lives of the mRNAs

29 in other groups, mainly those related to translation,

30 are more affected by thiolutin. Because it is known

31 that different mRNA degradation pathways act

32 in parallel (Parker and Song, 2004), this would

33 indicate that, for those mRNAs, the pathway(s)

34 inhibited by thiolutin have an increased importance

35 with regard to the average of yeast genes. was probably the reason why mRNA half-lives 52 were slightly longer when measured by thiolutin 53 treatment than by other techniques (Herrick et al., 54 1990). We recommend to check which is the right 55 concentration of thiolutin for each strain to avoid 56 secondary effects.

\section{Acknowledgements}

We wish to thank Sergi Puig, Lorena Romero, Oreto Antúnez and Paula M. Alepuz for helpful comments and discussion, the Servicio de Chips de DNA-SCSIE de la Universitat de València for printing DNA arrays and $\mathrm{J}$. García-Martínez for his skilful work. This work was funded 64 by Grants Nos BMC2003-07072-C03-02 and BFU2006- 65 15446-C03-02 from Ministerio de Educación y Ciencia 66 and No. ACOMP06/004 from Generalitat Valenciana to 67 J.E.P.-O. V.P. is a fellowship holder of the Conselleria de 68 Educació i Ciència de la Generalitat Valenciana.

\section{References}

Alberola TM, García-Martínez J, Antúnez O, et al. 2004. A new 73 set of DNA macrochips for the yeast Saccharomyces cerevisiae: 74 features and uses. Int Microbiol 7: 199-206.

Benard L. 2004. Inhibition of $5^{\prime}$ to $3^{\prime}$ mRNA degradation under stress conditions in Saccharomyces cerevisiae: from GCN4 to MET16. RNA 10: 458-468.

Brendolise C, Rouillard JM, Dufour ME， Lacroute F. 2002. 78 Expression analysis of RNA14, a gene involved in mRNA $3^{\prime} 79$ end maturation in yeast: characterization of the rnal45 ${ }^{-}$mutant 80 strain. Mol Genet Genom 267: 515-525.

Brengues M, Teixeira D, Parker R. 2005. Movement of eukaryotic mRNAs between polysomes and cytoplasmic processing bodies. Science 310: 4864-489.

Celmer WD, Solomons IA 1955 . The structures of thiolutin and aureothricin, antibiotics containing a unique pyrrolinonodithiole nucleus. $J$ Am Chem Soc 77: 2861-2865.

Cheadle C, Fan J, Cho-Chung YS, et al. 2005. Control of gene expression during $\mathrm{T}$ cell activation: alternate regulation of mRNA transcription and mRNA stability. BMC Genom 6: 75.

García-Martínez J, Aranda A, Pérez-Ortín JE. 2004. Genomic run-on evaluates transcription rates for all yeast genes and identifies gene regulatory mechanisms. Mol Cell 15: 303-313.

Grigull J, Mnaimneh S, Pootoolal J, Robinson MD, Hughes TR. 2004. Genome-wide analysis of mRNA stability using transcription inhibitors and microarrays reveals posttranscriptional control of ribosome biogenesis factors. Mol Cell Biol 24: $5534-5547$.

Guan Q, Zheng W, Tang S, et al. 2006. Impact of nonsense- 95 mediated mRNA decay on the global expression profile of 96 budding yeast. PLoS Genet 2: e203.

Herrick D, Parker R, Jacobson A. 1990. Identification and 98 comparison of stable and unstable mRNAs in Saccharomyces 99 cerevisiae. Mol Cell Biol 10: 2269-2284.

Hilgers V, Teixeira D, Parker R. 2006. Translation inhibition 100 of mRNA deadenylation during stress in Saccharomyces 101 cerevisiae. RNA 12: 1835-1845. 
Jiménez A, Tipper DJ, Davies J. 1973. Mode of action of thiolutin, an inhibitor of macromolecular synthesis in Saccharomyces cerevisiae. Antimicrob Agents Chemother 3: 729-738.

Jorgensen P, Rupes I, Sharom JR, et al. 2004. A dynamic transcriptional network communicates growth potential to ribosome synthesis and critical cell size. Genes Dev 18: 2491-2505.

Khachatourians GG, Tipper DJ. 1974. In vivo effect of thiolutin on cell growth and macromolecular synthesis in Escherichia coli. Antimicrob Agents Chemother 6: 304-310.

Mata J, Marguerat S, Bahler J. 2005. Post-transcriptional control of gene expression: a genome-wide perspective. Trends Biochem Sci 30: 506-514.

Michan C, Monje-Casas F, Pueyo C. 2005. Transcript copy number of genes for DNA repair and •translesion synthesis in yeast: contribution of transcription rate and mRNA stability to the steady-state level of each mRNA along with growth in glucose-fermentative medium. DNA Repair 4: 469-478.

Minvielle-Sebastia L, Winsor B, Bonneaud N, Lacroute F. 1991. Mutations in the yeast RNA14 and RNA15 genes result in an abnormal mRNA decay rate; sequence analysis reveals an RNA-binding domain in the RNA15 protein. Mol Cell Biol 11: 3075-3087.

Parker R, Herrick D, Peltz SW, Jacobson A. 1991. Measurement 36 of mRNA decay rates in Saccharomyces cerevisiae. Methods 37 Enzymol 194: 415-423.

Parker R, Song H. 2004. The enzymes and control of eukaryotic 38 mRNA turnover. Nat Struct Mol Biol 11: 121-127.

Pérez-Ortín JE, Alepuz P y Moreno J. 2007. Genomics and the 40 gene transcription kinetics in eukaryotes. Trends Genet 23: 41 250-257. tionship between mRNA stability and length in Saccharomyces 43 cerevisiae. Nucleic Acids Res 14: 8347-8360.

Sheth U, Parker R. 2003. Decapping and decay of messenger RNA 45 occur in cytoplasmic processing bodies. Science 300: 805-808. 46

Sunnerhagen P. 2007. Cytoplasmatic post-transcriptional regula- 47 tion and intracellular signalling. Mol Gen Genom 277: 341-355.

Tipper DJ. 1973. Inhibition of yeast ribonucleic acid polymerases 48 by thiolutin. J Bacteriol 116: 245-246.

Wang Y, Liu CL, Storey JD, et al. 2002. Precision and functional 50 specificity in mRNA decay. Proc Natl Acad Sci USA 99: 51 5860-5865. 